\title{
Multi-criteria analysis for mapping susceptibility to iron formation caves development in the Gandarela mountain range (MG), southeast Brazil
}

\author{
Iraydes T.S. Nola (1) ${ }^{1 *}$ and Luis A.P. Bacellar (10 ${ }^{2}$ \\ ${ }^{1}$ Faculty of Geosciences, Federal University of Mato Grosso, Av. Fernando Corrêa da Costa, 2367, 78060-900, Cuiabá, Mato Grosso, Brazil \\ ${ }^{2}$ Geotechnical Group, Federal University of Ouro Preto, Campus Morro do Cruzeiro, 35400-000, Ouro Preto, Minas Gerais, Brazil
}

\begin{abstract}
In tropical regions, abundant in iron-rich geological materials, caves that are genetically and geographically associated with exploitable mineral deposits may develop. These caves have speleological relevance and are environmentally and legally protected in Brazil. Thus, for better planning of exploitation and environmental licensing, it is necessary to study the genesis and development of the iron formation caves seeking to preserve them without impeding the advancement of mining. This subject is complex, rarely studied, and few are the knowledges on alternatives to predict the occurrence of these caves. This gap justifies the development of research and products capable of assisting decision-makers, planners, and competent authorities in supporting the definition of target sites for speleological prospecting in the field. In this study, the prediction of the factors involved in the development of iron formation caves was evaluated producing a map of susceptibility in a GIS environment using fuzzy logic and an analytical hierarchic process (AHP). Therefore, the variables: iron oxide ratio, slope gradient, normalised difference vegetation index (NDVI), plan curvature, profile curvature, lineament intensity, and height above the nearest drainage (HAND) were selected. These variables were obtained by processing of geospatial data from a region of the Gandarela Range (Minas Gerais, Brazil). The fuzzy logic and AHP techniques were applied, and for the validation of the results, a previously surveyed cave inventory was used. The results showed satisfactory performance of the map produced in predicting areas favourable to the occurrence of iron formation caves, presenting an area under the receiver operating characteristic (ROC) curve of approximately 0.85 , which indicates a high prediction rate and validates the proposed method. Such results demonstrate that this susceptibility map was reliable and that the set of criteria and weights used were suitable for mapping areas favorable for speleological prospecting.
\end{abstract}

Keywords: $\quad$ iron formation caves, susceptibility map, analytical hierarchy process, fuzzy logic, Brazil

Received 22 January 2021; Revised 19 April 2021; Accepted 28 April 2021

Citation: Nola, I.T.S., Bacellar, L.A.P., 2021. Multi-criteria analysis for mapping susceptibility to iron formation caves development in the Gandarela mountain range (MG), southeast Brazil. International Journal of Speleology, 50(2), 173-187. https://doi.org/10.5038/1827-806X.50.2.2376

\section{INTRODUCTION}

Among the environments favorable to the development of karst relief forms, those associated with the dissolution of limestone rocks are best known in a global context. However, also other types of rocks, such as quartzite, sandstone, granite, and shale, may develop karstic forms (Webb \& Finlayson, 1984; Piccini \& Mecchia, 2009; Sauro et al., 2014; Agapov et al., 2016; Holler, 2019). Karst features have also been described in iron-rich geological materials, usually in tropical regions, since the beginning of the 20th century (Gautier, 1906; Dixey, 1920; Jutson, 1914). According to Maurity (1995), karst features in iron formations have been found in India, Australia, Brazil and several countries of Africa.

In Brazil, the first records of this type of karst date from the 19th century (Souza \& Carmo, 2015), but specific studies were only carried out in the middle of the 20th century (Guild, 1957; Simmons, 1963).

The Brazilian iron formation caves mainly develop in the Ferriferous Quadrangle (FQ) and Carajás Mineral Province (CMP). In these areas, iron-rich geological materials occur, such as itabirites, banded 
iron formations, hematitic phyllites, and supergene materials such as ferricrete ("cangas") (Auler \& Farrant, 1996).

Similar to their counterparts in karst environments, the caves in iron formations have great speleological (Souza \& Carmo, 2015), archaeological (Baeta \& Piló, 2015; Carmo \& Kamino, 2017) and palaeontological (Frank et al., 2012; Bittencourt et al., 2015) relevance. The iron formation caves also present peculiar biodiversity, containing extremely complex organisms, mainly troglomorphic, many of which have not yet been taxonomically described (Pipan \& Culver, 2019); these comprise populations restricted to the humid and low luminosity underground environments (Ferreira, 2005; Souza-Silva et al., 2011).

There is a close genetic and geographical relationship between iron deposits and these caves (Souza \& Carmo, 2015). Therefore, the occurrence of one or more iron formation caves in a mineral exploitation area may significantly affect mining planning, reducing economically minable iron reserves (Brandi et al., 2015). Thus, iron formation caves are often subject to legal restrictions in the face of mineral resource exploitation, which leads to intense economic and political pressure (Auler \& Piló, 2015; Barbosa et al., 2019). Therefore, an important variable in mineral exploitation planning and environmental licensing is the identification and understanding of the genesis of iron formation caves, to meet the principles of sustainable development by preserving the caves without impeding the advancement of mining.

Some authors have investigated the genesis of these caves (e.g., Twidale, 1987; Grimes \& Spate, 2008; Auler et al., 2014, 2019; Calux et al., 2019), but there are still many questions to be answered. Therefore, limited understanding of the genesis and, consequently, the geographic occurrence of these caves has not yet been addressed.

One of the techniques widely used in decision making for complex problems is multicriteria analysis through analytical hierarchy process (AHP). AHP combines information, knowledge, and expert judgment in an efficient and systematic manner. This combination helps meet the need for several types of assessments such as landslide susceptibility mapping (Kayastha et al., 2013), geological disasters (Wang \& Yi, 2009), flood risk (Ghosh \& Kar, 2018; Chakraborty \& Mukhopadhyay, 2019), and in the case of karst relief forms, sinkhole susceptibility mapping (Taheri et al., 2015; Calligaris et al., 2017). However, studies applying this technique to map the susceptibility to iron formation caves development are still scarce in literature, which justifies further research on this subject.

Despite its wide application, one of the criticisms of AHP is the failure to address the uncertainties of pairwise comparison judgments (Pourghasemi et al., 2012). This failure is because decision-makers choose to express judgements in intervals rather than exact numerical values (Najafi et al., 2014), which do not replicate human mental processes (Zhang et al., 2017). An alternative solution to this problem is the combination of the AHP technique and fuzzy logic (Yang et al., 2013).
Fuzzy logic enables the standardization of criteria by considering a continuous scale of data, making it more realistic than Boolean logic, which standardises the data by binary association (Ghosh et al., 2012). The use of fuzzy pertinence functions seeks to prevent classes from being grouped into fixed limits. This process is important for comparison of criteria by direct aggregation. The combination of AHP and fuzzy logic solves the problem of effective decisionmaking for multiple attributes (Yang et al., 2013), allowing more flexible combinations of weighted data.

Thus, the present work aims to map the susceptibility to iron formation caves development in Gandarela Range, a significant Brazilian mining region, through multicriteria analysis using AHP and fuzzy logic. This work is of great relevance as the numerous caves present in this mountain range have made it difficult or impossible to extract important deposits of iron ore, which represent one of the main commodities of the Brazilian economy.

\section{STUDY AREA}

The Gandarela Mountain Range ("Serra do Gandarela") is located in the southern central portion of the state of Minas Gerais (southeast of Brazil), constituting the most environmentally preserved area of the Iron Quadrangle (Marent \& Portilho, 2017). This region is part of the Serra do Gandarela National Park (SGNP), created to protect and preserve biological, geological, hydrological, and speleological diversity. The region also accommodates geomorphological complexes composed of mountains and plateaus associated with the ferricrete, including rupestrian grassland and remnants of the Atlantic Forest (Brazilian Government, 2014). The Iron Quadrangle is one of the largest mineral provinces in the world (Dorr, 1969), with vast reserves, especially of iron, gold, and aluminium.

A $7.2 \mathrm{~km}^{2}$ polygon was selected as a study area in an NW oriented section of the mountain range where the largest amount of known natural iron formation caves in the region are concentrated (Fig. 1). The vegetation includes semi-deciduous seasonal forests (representatives of the Atlantic Forest), gallery forest, and rupestrian grasslands (Oliveira et al., 2005; Fernandes, 2016), which are associated with ferricrete exposure and characterised by herbaceous species typical of higher altitudes.

The exposed geological units are part of a metasedimentary sequence from the Paleoproterozoic, consisting of itabirites, dolomites, dolomitic itabirites, and hematitic phyllites (Dorr, 1969; Alkmin \& Marshak, 1998). Caves typically develop in ferricrete, at the tops of mountains that configure as plateaus.

Owing to the geological context associated with materials rich in iron and aluminium, mining companies have a great interest in the study region. Some interventions related to mineral prospecting, such as the exposed soil from trench opening and drilling, were present in the ferricrete plateaus before the creation of the SGNP. 

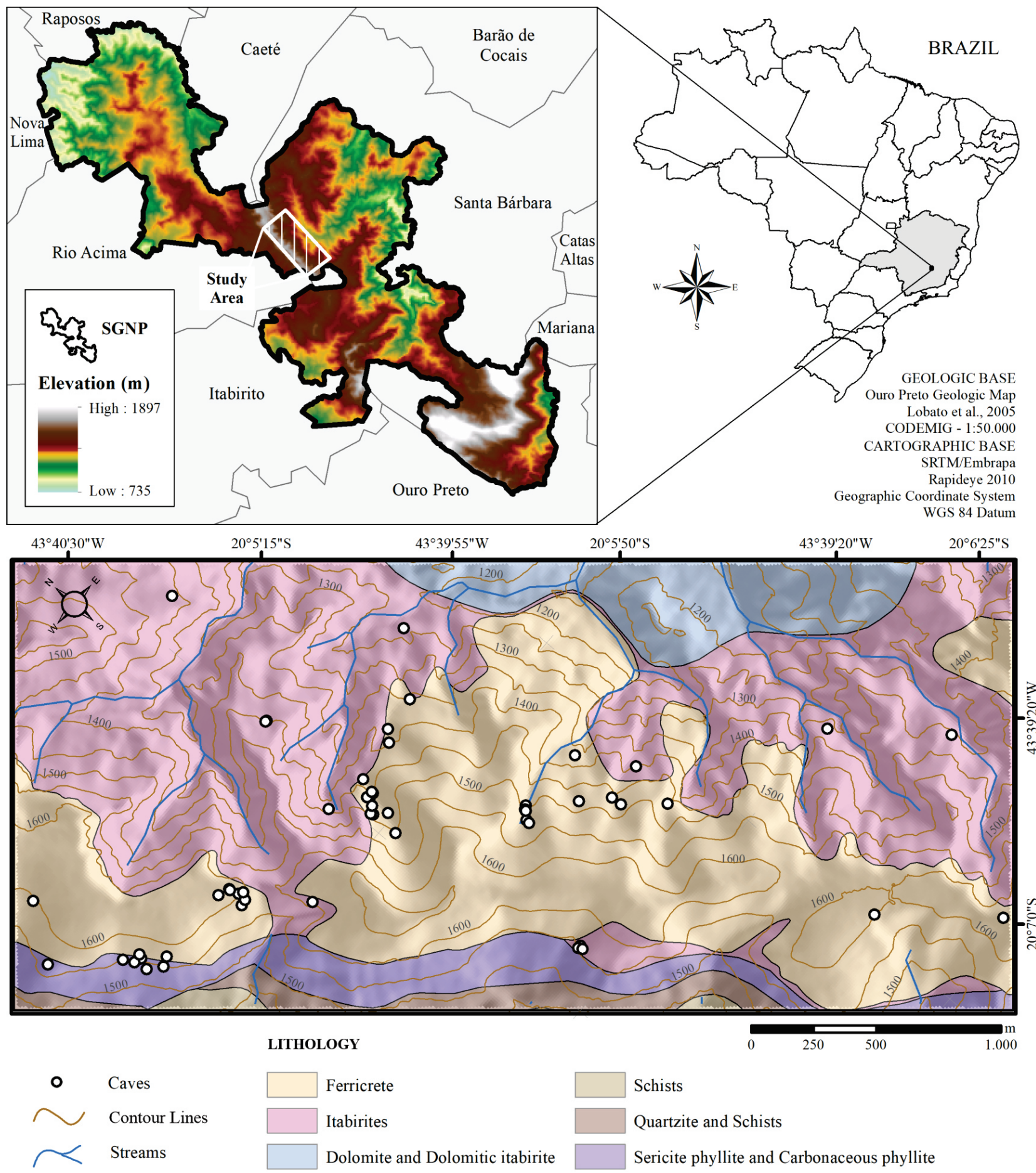

Fig. 1. Location map of the study area indicating elevation and the geological units.

The natural factors that condition the genesis of caves in iron formations are still poorly understood. However, works developed at FQ and CMP have indicated certain indexes and parameters that influence the genesis of these caves.

Iron formation caves usually have small dimensions (Piló \& Auler, 2009; Albuquerque et al., 2018), and are found at depths less than $5 \mathrm{~m}$ below the topographic surface (Auler et al., 2019). They develop concordantly with slope gradient (Auler et al., 2019; Piló \& Auler, 2009), although at a gentler angle (Fig. 2). The cave halls are small with irregular morphology (Fig. 2A, B), displaying pendants and pillars (Auler \& Piló, 2005; Auler et al., 2014). The entrance of the cavities is usually narrow and covered with vegetation (Simmons, 1963; Dutra, 2013). Fine and well-sorted ferriferous sediments and rock fragments from gravitational collapse processes are present on the floor (Fig. 2C) (Piló et al., 2015a; Dutra, 2017; Auler et al., 2019).

\section{MATERIALS AND METHODS}

\section{Criteria influencing the development of iron formation caves}

The iron formation caves in Brazil are associated with certain iron units, such as ferricrete, banded iron formations, and iron ores (Simmons, 1963; Dutra, 2013; Piló et al., 2015a; Auler et al., 2019), especially in the most iron-rich facies (Calux, 2013). Some caves develop at the interface between the ferricrete and banded iron formation, while others develop within 


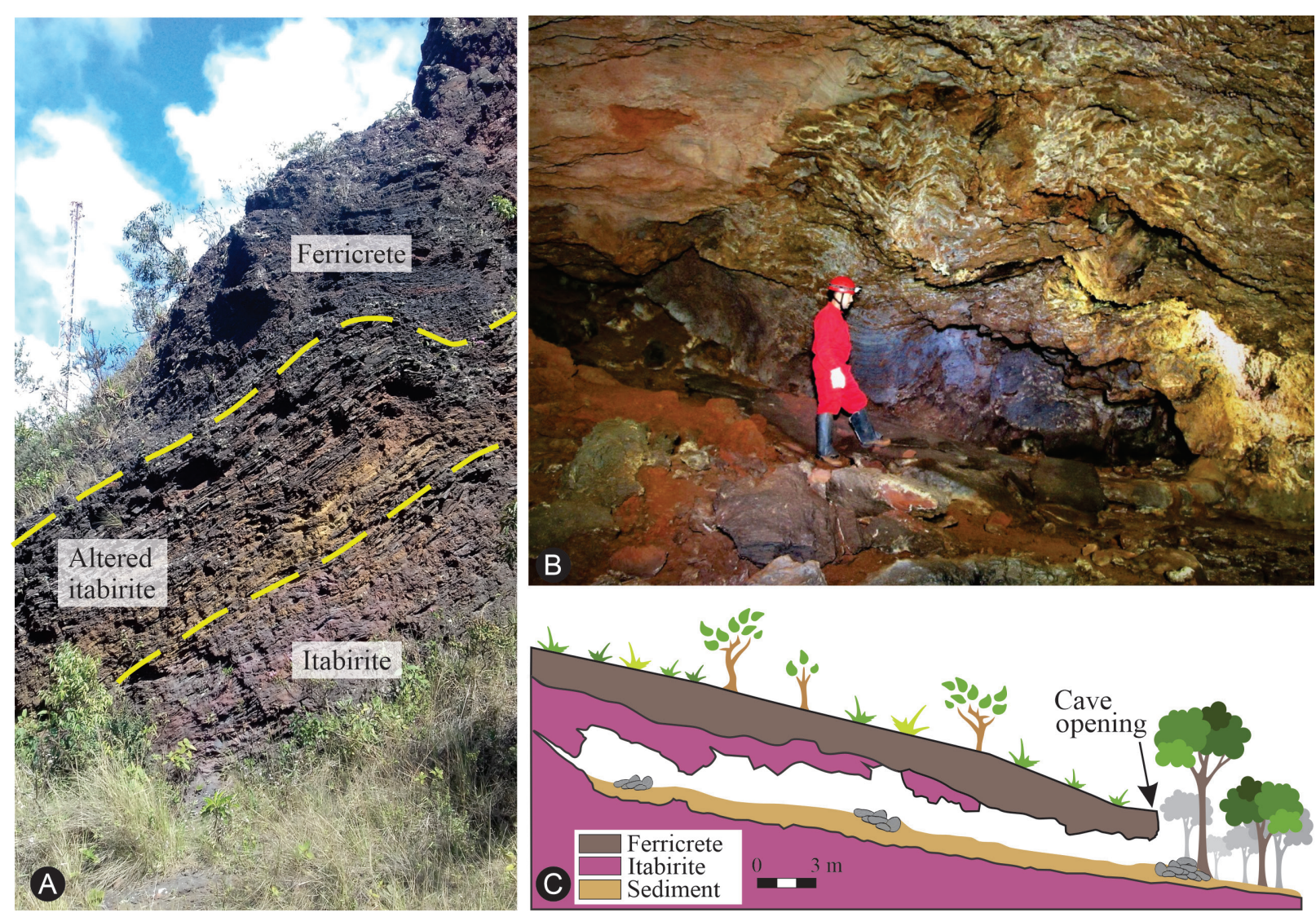

Fig. 2. A) Weathering profile of an itabirite outcrop; B) Iron formation cave in FQ with typical irregular morphology; C) Schematic geological cross-section of a typical iron formation cave.

the ferricrete formation (Auler et al., 2019). Therefore, an index that allows remote mapping of iron-rich geological materials will prove useful. There are several indices commonly used in digital image processing to identify iron-rich targets, as iron oxide causes absorption in the region of the spectral bands of blue and green and an increase in reflectance in the red band (Jensen, 2009). Among these, the iron oxide ratio (IOR) (Segal, 1982), representing the ratio between the spectral bands corresponding to red and blue, is often reported. This index has been used to discriminate iron oxides in lithological mapping (Ciampalini et al., 2013; Mazhari et al., 2017; Gopinathan et al., 2020), with good results, including under vegetation cover in the CMP region (Ducart et al., 2016).

Morphometric parameters are of fundamental importance in several geodynamic processes, such as erosion (Bacellar et al., 2005), mass movements (Lee et al., 2004; Di Napoli et al., 2020), and even in the development of iron formation caves (Simmons, 1963; Piló \& Auler, 2009; Auler et al., 2019). Among these parameters, the slope gradient (SP) and curvature are frequently used.

The increase in slope favours surface and subsurface water runoff and the consequent erosion process, both geochemical and mechanical (Huggett, 2011; Summerfield, 2014). Indeed, Leite (1985) shows that chemical leaching tends to increase with the intensity of interflow. Similarly, the curvature represents the shape of the terrain surface, allowing the assessment of the slope ability to control the flow of water through runoff (Wysocki et al., 2011) and subsurface runoff (Steenhuis et al., 2005). This runoff influences sediment distribution (Pahlavan-
Rad et al., 2016), vegetation (Florinsky \& Kuryakova, 1996), and the intensity of geodynamic processes (Pourghasemi et al., 2012; Arabameri \& Pourghasemi, 2019). The curvature can be expressed both in terms of the plan and profile curvature (Ruhe, 1975). The plan curvature (PLC) depicts the shape of the terrain surface perpendicular to the direction of the maximum slope (Wilson \& Gallant, 2000). It is associated with the ability of the water to converge or diverge on the slope (Wysocki et al., 2011). The profile curvature (PRC) depicts the shape of the surface parallel to the slope, i.e., in the direction of slope flow. It controls changes in flow velocity and sediment transport processes (Wilson \& Gallant, 2000).

In this sense, Dutra (2013) states that the iron formation caves tend to develop on high to medium slopes, mainly in drainage headwaters with concave geometry in terms of plan and profile. Iron formation caves are frequent on the edges of plateaus and in small topographic relief breaks across stretches of slopes, as well as in the surroundings of drainage channels and lagoons (Simmons, 1963; Piló and Auler, 2009; Dutra, 2013).

Many authors (Calux, 2013; Piló et al., 2015b; Dutra, 2017; Calux et al., 2019) point out that the iron formation caves begin in a phreatic or transitional environment and evolve in the vadose zone. Despite being mostly humid, the caves do not present permanent water flows or significant water bodies (Dutra, 2013; Auler et al., 2014), and those with internal hydrological interconnection are rare (Calux \& Cassimiro, 2015). Such findings indicate that currently, the caves are above the regional water table (Auler et al., 2019), which is often tens of metres 
deep (Calux \& Cassimiro, 2015). However, after significant rainfall events, water inflow through the caves is observed, which percolates via fractures or bio pores (Dutra, 2013). In these cases, some flow may develop at the bottom of the caves as interflow (Freeze $\&$ Cherry, 1979), which could be added to the runoff and feed the temporary drainage channels identified downstream. Therefore, the temporary drainage channels tend to be related to the interflows identified in the caves. These interflows constitute temporary saturation zones above the regional phreatic surface.

The height above the nearest drainage (HAND) model proposed by Rennó et al. (2008) enables the assessment of the depth of temporary saturation zones. This model is created by extracting the vertical distance (relative difference) of each pixel from the digital elevation model (DEM) concerning the altitude position of the nearest drainage channel. This indicates the topographic normalisation of the landscape by the local drainage network, using the area of contribution of this drainage as the process threshold. The values produced by the HAND model are directly related to the possible depth of the saturation surface feeding the drainage channels. Theoretically, the lower the HAND value, the greater the proximity of the terrain surface to the subsurface saturation level (Nobre et al., 2011), which in other situations represents the regional water table surface. This value justifies the application of the HAND model in studies related to soil hydrological characteristics (Gharari et al., 2011) in mapping areas subject to flooding (Nobre et al., 2016; Zhang et al., 2018), and morphodynamic processes (Kornejady et al., 2017).

Another relevant factor is the vegetation, which is directly associated with the bedrock and the topography (Lamounier et al., 2010). Thus, in ironenriched regions where iron formation caves develop, like in ferricrete and itabirite outcrops, there is little to no soil formation and vegetation tends to be rarefied, classified as a ferruginous rupestrian grassland (Stávale, 2012; Piló et al., 2015a). In the context of FQ, rupestrian grassland is distributed in the highest parts of the relief.

Piló et al. (2015b) point out that canga substantially influences the floristic composition of rupestrian grasslands, including some endemic species (Mota et al., 2015). Iron formation caves are frequent in topographic breaks (Piló \& Auler, 2009; Dutra, 2013; Auler et al., 2019), where talus deposits usually occur in association with large vegetation cover. Moreover, more developed vegetation patches inside plateaus with rupestrian grassland may represent collapsed caves or dolines (Pereira et al., 2012).

Therefore, indices that discriminate the various types of vegetation can be useful to distinguish areas that are susceptible to the development of iron formation caves. Among the most used indices, the normalised difference vegetation index (NDVI) stands out; this is a dimensional radiometric measurement given by the normalised ratio of multispectral images between the near-infrared (NIR) and red (Red) bands of reflectance (Jensen, 2009) (Eq. 1). NDVI values indicate the density and vigour of the surface vegetation cover; the higher its value, the greater the amount of green vegetation (Holben, 1986). Valid NDVI values lie on a scale ranging from -1 to +1 .

$$
\mathrm{NDVI}=(\mathrm{NIR}-\mathrm{Red}) /(\mathrm{NIR}+\mathrm{Red}) \quad \text { (Eq. 1) }
$$

Morphostructural lineaments are superficial linear features associated with some geological or geomorphological structures, such as faults, fracture zones, joints, ridges, and aligned valleys (Clark \& Wilson, 1994; Rogers \& Engelder, 2004). They can be easily identified through aerial photographs or radar images (Sabins Jr, 1987; Casas et al., 2000). This variable is hydrogeologically important as it tends to indicate the path of water infiltration and percolation in low permeable rock mass. The factors considered most relevant for water circulation in rock mass with low primary porosity and permeability are intensity, aperture, and connectivity of discontinuities (Singhal $\&$ Gupta, 2010). As there are several patterns of discontinuities in the ferricrete region (Dutra, 2017), the connectivity can be considered good. Fracture aperture is a difficult parameter to measure in this region, as a single discontinuity may present a variation of this parameter in depth due to the continuous processes of dissolution and precipitation, common in the ferricrete (Ferreira, 2005; Spier et al., 2019). As there is a good correlation between lineament and fracture directions in the region (Dutra, 2017), the lineament intensity (LI) (National Research Council, 1996) becomes the only reliable variable for an indirect evaluation of superficial permeability (Florinsky, 2016). Therefore, this variable can be used in the study of groundwater recharge (Senanayake et al., 2016) and mapping groundwater zones (Srivastava \& Bhattacharya, 2000; Magesh et al., 2012). In addition, tectonic planar structures, especially foliation planes and fractures, control the genesis and development of iron formation caves (Piló et al., 2015a). Structural conditioning is also marked by narrow passages between chambers, elongated chambers, conduit directions reflecting the main fracture orientations, and semi-parallel or parallel conduits (Piló \& Auler, 2009; Dutra, 2013; Auler et al., 2019). The ferricretes in the FQ region are generally not permeable (Dorr, 1969; Souza, 2018), and discontinuities exert the main role for water circulation and spatial and temporal development of caves (Dutra, 2017). Therefore, any indicator that indirectly represents the intensity of fractures, such as lineament intensity, tends to have good significance for the genesis of caves.

\section{Data processing}

For the mapping of the susceptibility of iron formation caves, a model using fuzzy logic and AHP was proposed in this study, applied in a GIS environment, and later validated following the procedures illustrated in Figure 3. Among the criteria selected for the susceptibility analysis, the following seven were used: iron oxide ratio, slope gradient, NDVI, PLC, PRC, lineament intensity, and HAND.

The geospatial data processing was performed with ArcGIS (ESRI, 2012), Terra View (INPE, 2019), ENVI (ENVI, 2001), and IDRISI Selva (Eastman, 2012) 
software. A 10-m cell was selected as the base resolution to maintain spatial consistency and facilitate operation between different rasters. Preparation procedures for each data layer are summarised below.

The iron oxide ratio (IOR) was determined based on satellite images from the Sentinel 2A mission, capturing high resolution multispectral bands. The scene used in this study corresponds to the processing level $1 \mathrm{C}$, where the images are orthorectified with top The 10-m resolution bands 2 (490 nm) and 4 (665 $\mathrm{nm}$ ) captured on $13 / 07 / 2016$ by the Multi-Spectral Instrument (MSI) were used according to Eq. 2. This scene was collected free of charge from the European Space Agency (ESA).

Iron Oxide Ratio = band $4 /$ band 2

(Eq. 2) atmosphere reflectance values (TOA) (ESA, 2015).

The slope gradient (SP), curvature, in terms of PLC and PRC, and the HAND were produced from a 10-m resolution DEM, derived from a cloud of points acquired by LIDAR. The treatment and filtering of the vegetation cover from the point cloud, as well as the creation of the DEM, were processed using LAStools software, while the HAND model was produced using Terra View software (INPE, 2019).

The NDVI was determined using bands 3 (630 to $690 \mathrm{~nm})$ and 5 (760 to $880 \mathrm{~nm}$ ) captured by the satellites of the RapidEye mission, with the RapidEye Earth Imaging System (REIS) sensor. The orthorectified scene has a resolution of $5 \mathrm{~m}$ and was ceded by the Minas Gerais State Forest Institute (IEF). The resolution of the scenes was changed to $10 \mathrm{~m}$ in order to standardise the database.

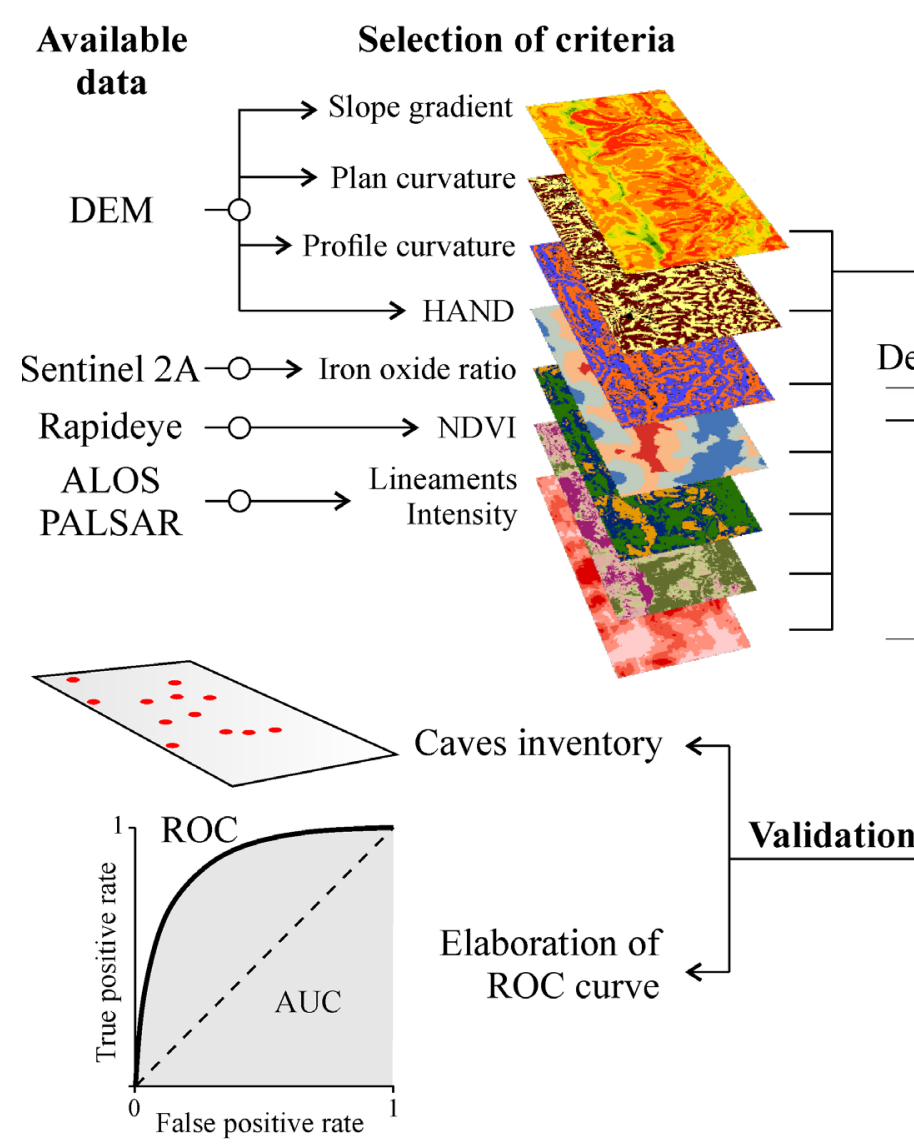

Fig. 3. Flow chart for iron formation caves susceptibility assessment.

In this study, the morphostructural lineaments were drawn based on a set of shaded relief rasters with different lighting directions, generated from the radar image (ALOS/PALSAR). This $12.5 \mathrm{~m}$ resolution image was captured by Advanced Land Observing Satellite (ALOS) with the Phased Array type L-band Synthetic Aperture Radar (PALSAR) sensor and obtained free of charge from the Alaska Satellite Facility (ASF) database. Therefore, the lineament intensity was obtained adding all the lineament lengths distributed over a defined area of radius $=150 \mathrm{~m}$.

An inventory of iron formation caves was prepared to assist the process of evaluation and validation of results. Data were collected from the Brazilian Speleological Information Registry (CECAV, 2019) and 55 caves associated with iron formations were found in the study area.

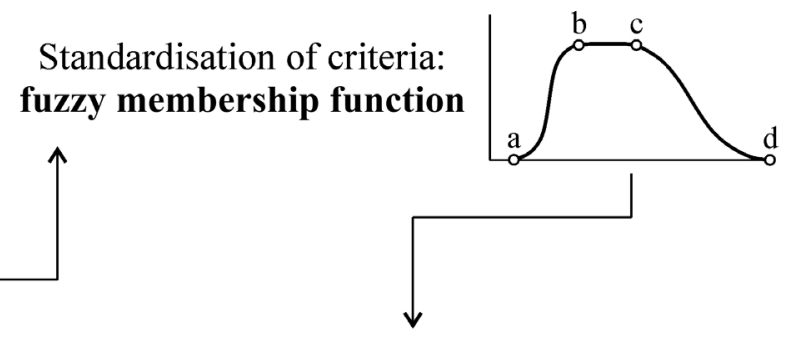

Determination of criteria weight: AHP

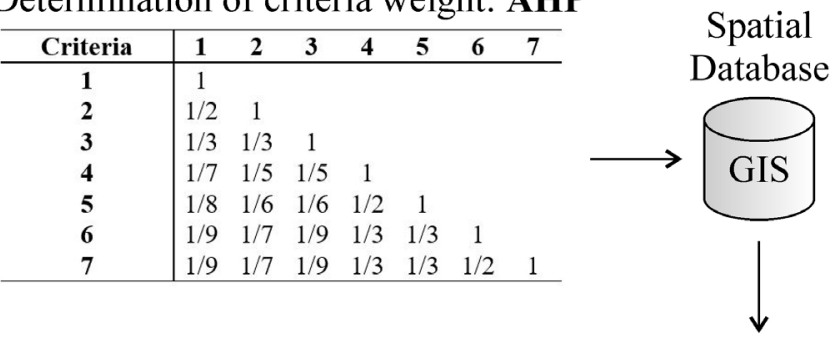

Combination of criteria: weighted linear combination

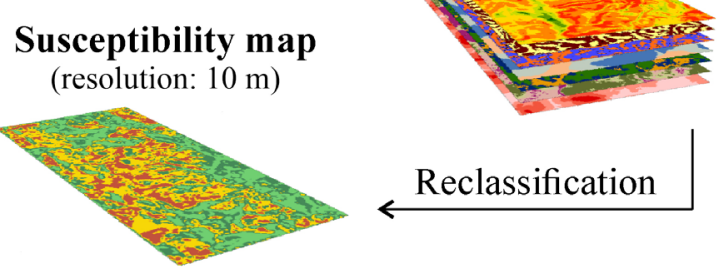

The cave inventory was randomly divided into two groups: a training group (Group 1), with $70 \%$ of the iron formation caves used for the standardisation of criteria by fuzzy logic, and a validation group (Group 2 ), with $30 \%$ of iron formation caves, used for the validation of the result.

\section{Standardisation of criteria using fuzzy sets theory}

The inventory was standardised using fuzzy logic to attain the weighted linear combination (WLC) of the different criteria (Zadeh, 1965). This type of standardisation considers a continuous scale of the data, making it more realistic than Boolean logic, which standardises the data by binary association (Ghosh et al., 2012). The use of fuzzy pertinence functions seeks to prevent classes from being grouped 
into fixed limits, ensuring a continuous and more realistic variation (Schicker \& Moon, 2012).

Fuzzy logic can be used in datasets of any measuring scale as the weighting of the criteria is entirely controlled by the expert, making it a simple technique to understand and easy to implement (Pourghasemi et al., 2012).

In this study, the original values of each criterion were replaced by continuous and dimensionless values, ranging from 0 (unfavorable) to 1 (favorable), indicating a symmetric sigmoid type fuzzy pertinence function (Brito et al., 2017), a function that best fitted the database.

The control points of the symmetric sigmoid function were determined from the mean and standard deviation of the values of each criterion. These values were obtained by overlaying the pixels of the iron formation caves (Group 1) on the respective pixels of the adopted criteria.

Table 1 presents the control points $(\mathrm{a}, \mathrm{b}, \mathrm{c}, \mathrm{d})$ obtained from the standardisation method used. The points a and $\mathrm{d}$ correspond to the mean minus standard deviation and mean plus standard deviation, respectively. Points $\mathrm{b}$ and $\mathrm{c}$ correspond to the mean values minus half the standard deviation and mean plus half the standard deviation, respectively. This standardisation technique aims to reduce human uncertainty in the decision making when considering the relevance of the values of each sub-criterion individually. Therefore, this step becomes essential in the preparation of data for AHP application in susceptibility mapping.

Table 1. Control points from the fuzzy relevance function to the criteria.

\begin{tabular}{|l|c|c|c|c|}
\hline \multirow{2}{*}{\multicolumn{1}{c|}{ Criteria }} & \multicolumn{4}{c|}{ Control points } \\
\cline { 2 - 5 } & $\boldsymbol{\mu}-\boldsymbol{\sigma}$ & $\boldsymbol{\mu}-\mathbf{\sigma / 2}$ & $\boldsymbol{\mu}+\boldsymbol{\sigma / 2}$ & $\boldsymbol{\mu}+\boldsymbol{\sigma}$ \\
\cline { 2 - 5 } & $\mathbf{a}$ & $\mathbf{b}$ & $\mathbf{c}$ & $\mathbf{d}$ \\
\hline Iron Oxide Ratio (IOR) & 0.553 & 0.617 & 0.746 & 0.811 \\
\hline Slope Gradient (SP) & 29.673 & 38.809 & 57.081 & 66.218 \\
\hline NDVI & 0.175 & 0.235 & 0.356 & 0.416 \\
\hline Plan Curvature (PLC) & -1.371 & -0.807 & 0.321 & 0.885 \\
\hline Profile Curvature (PRC) & -0.740 & -0.378 & 0.345 & 0.706 \\
\hline Lineament Intensity (LI) & 7.825 & 8.956 & 11.218 & 12.349 \\
\hline HAND & 103.727 & 139.853 & 212.103 & 248.228 \\
\hline
\end{tabular}

\section{Analytical Hierarchy Process (AHP)}

AHP is a multi-criteria analysis method proposed by Saaty $(1996,2004)$, which uses the relative importance of criteria compared in pairs to give weight to each criterion in front of the problem exposed and thus, generates a solution for complex decisions.

The AHP can be divided into four stages (Tzeng \& Huang, 2011): (1) creation of a hierarchical system from the decomposition of the problem into interrelated elements; (2) creation of the matrix of comparison in pairs between the criteria based on the attribution of the values of the scale of importance suggested by Saaty (1996, 2004), as presented in Table 2; (3) summarisation of the subjective judgments of the criteria and weighting of the relative weights from the calculation of the standardised autovector; and (4) aggregation of the relative weights to formulate the best alternative.

Table 2. Scale of importance between the criteria (Saaty 1996, 2004).

\begin{tabular}{|l|c|c|}
\hline \multicolumn{1}{|c|}{ Intensity of importance } & Definition & Explanation \\
\hline 1 & Equal importance & Two activities contribute equally to the objective \\
\hline 3 & Moderate importance & $\begin{array}{c}\text { Experience and judgement slightly favor one activity over } \\
\text { another }\end{array}$ \\
\hline 5 & Strong importance & $\begin{array}{c}\text { Experience and judgement strongly favor one activity over } \\
\text { another }\end{array}$ \\
\hline 9 & Extremely important & $\begin{array}{c}\text { Activity is strongly favored and its dominance } \\
\text { demonstrated in practice }\end{array}$ \\
\hline $2,4,6,8$ & $\begin{array}{c}\text { Thterme evidence favoring one activity over another is the } \\
\text { highest possible order of affirmation }\end{array}$ \\
\hline
\end{tabular}

\section{Iron formation caves susceptibility}

In this study, the susceptibility to development of iron formation caves (CS) was integrated by a weighted linear combination of fuzzified criteria. The product is the iron formation caves susceptibility map that is represented by a raster file whose pixel values correspond to the CS values. This integration was performed pixel by pixel resulting in a continuous value ranging from 0 (lower susceptibility) to 1 (higher susceptibility). The Natural Break (Jenks) classifier of the GIS environment (Calligaris et al., 2013; Myronidis et al., 2016) was used to determine the four classification ranges: very high, high, moderate, and low.

\section{Validation}

Validation is the most important step in the classification process, as it enables the analysis of the predictive capacity of the method (Hasekiogullari \& Ercanoglu, 2012; Wu et al., 2018; Roodposhti et 
al., 2014; Kumar \& Anbalagan, 2016). In this work, two forms of validation were used: the first consisted of superimposing the inventory on the map and visually evaluating the distribution of caves over the classes. The second consisted of receiver operating characteristic (ROC) analysis, which is widely used in the evaluation of classification methods (Nicu, 2018; Das \& Pal, 2019; Kadam et al., 2019). The ROC analysis consists of correlating the rate of true positives (correctly classified cave data) and the rate of false positives (incorrectly classified cave data). From this operation, the area under the receiver operating characteristic curve (AUC) can be determined, with an AUC result close to 1 regarded as excellent. On the other hand, when the AUC value approaches its threshold, i.e., close to 0.5 , it is evident that the method could not separate the desired classes. The success rate was calculated based on the AUC of the training dataset (Group 1) and the
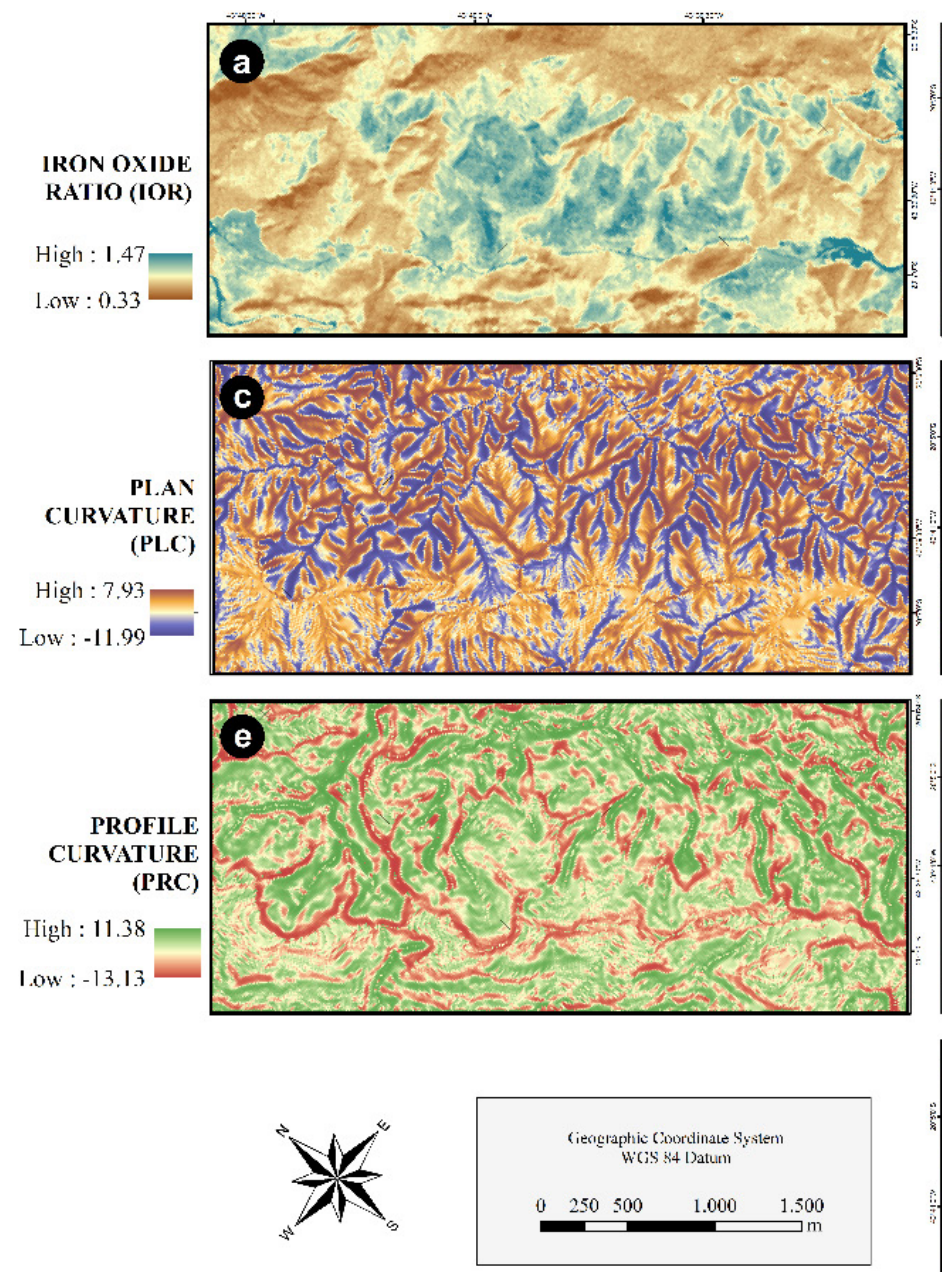

prediction rate was based on the validation dataset (Group 2).

\section{RESULTS}

Figure 4 presents the data layers with the results of the seven parameters investigated in the study area.

The weighting factors, evaluated pairwise, were applied to the seven criteria according to the importance of each criterion in relation to the susceptibility to development of iron formation caves, thus generating the comparison matrix. The calculation of the eigenvalues of the comparison matrix determines the weights of each criterion (Table 3). Table 3 demonstrates that the most important parameter in relation to the occurrence of iron formation caves is the iron oxide ratio, followed by the slope gradient and NDVI. The least important criteria are lineament intensity and HAND.
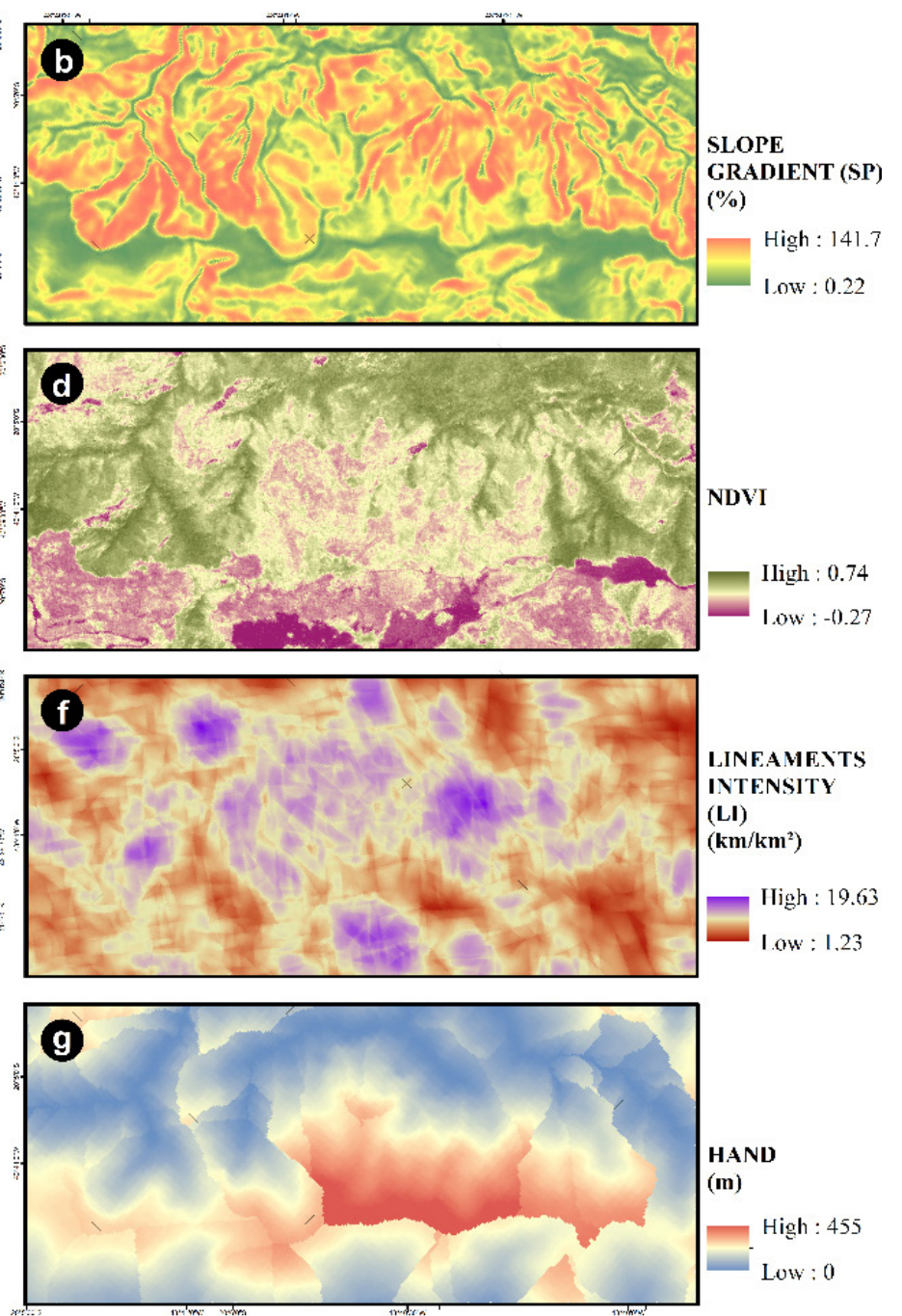

Fig. 4. Data layers: a) iron oxide ratio; b) slope gradient; c) plan curvature; d) NDVI; e) profile curvature; f) lineaments intensity; and g) HAND.

The consistency ratio $(\mathrm{CR})$ is used to evaluate the consistency of the classification by the weights in the AHP, for detecting contradictions in the determination of relative importance. The CR value (Eq. 3) is based on the consistency index (CI) (Eq. 4) and the random consistency index (RI) (Table 4), developed by Saaty (1996, 2004).

$$
\mathrm{CR}=\mathrm{IC} / \mathrm{RI} \quad \text { (Eq. 3) }
$$

where,

$$
\left.\mathrm{CI}: \lambda_{\max }-\mathrm{n} / \mathrm{n}-1 \quad \text { (Eq. } 4\right)
$$

$\lambda_{\max }:$ main eigenvalue;

$\mathrm{n}$ : number of criteria of the problem;

$\mathrm{RI}$ : random consistency index for each $\mathrm{n}$ value.

The value of the limit for CR is 0.1 (Saaty, 2004). Larger values indicate that the weights should be revised. The CR value, in the study, was exactly 0.1 , 
Table 3. Matrix for pair comparison, criteria weights, and consistency ratio.

\begin{tabular}{|l|c|c|c|c|c|c|c|c|}
\hline \multicolumn{1}{|c|}{ Criteria } & $\mathbf{1}$ & $\mathbf{2}$ & $\mathbf{3}$ & $\mathbf{4}$ & $\mathbf{5}$ & $\mathbf{6}$ & $\mathbf{7}$ & Weights \\
\hline Iron Oxide Ratio (IOR) & 1 & & & & & & & 0.367 \\
\hline Slope Gradient (SP) & $1 / 2$ & 1 & & & & & & 0.257 \\
\hline NDVI & $1 / 3$ & $1 / 3$ & 1 & & & & & 0.202 \\
\hline Plan Curvature (PLC) & $1 / 7$ & $1 / 5$ & $1 / 5$ & 1 & & & & 0.065 \\
\hline Profile Curvature (PRC) & $1 / 8$ & $1 / 6$ & $1 / 6$ & $1 / 2$ & 1 & & & 0.052 \\
\hline Lineament Intensity (LI) & $1 / 9$ & $1 / 7$ & $1 / 9$ & $1 / 3$ & $1 / 3$ & 1 & & 0.031 \\
\hline HAND & $1 / 9$ & $1 / 7$ & $1 / 9$ & $1 / 3$ & $1 / 3$ & $1 / 2$ & 1 & 0.025 \\
\hline
\end{tabular}

Table 4. Random consistency index (RI).

\begin{tabular}{|c|c|c|c|c|c|c|c|c|c|c|c|c|c|c|c|}
\hline $\mathbf{N}$ & 1 & 2 & 3 & 4 & 5 & 6 & 7 & 8 & 9 & 10 & 11 & 12 & 13 & 14 & 15 \\
\hline RI & 0 & 0 & 0.58 & 0.90 & 1.12 & 1.24 & 1.32 & 1.41 & 1.45 & 1.49 & 1.51 & 1.53 & 1.56 & 1.57 & 1.59 \\
\hline
\end{tabular}

suggesting that the judgments applied in pairwise comparison are consistent.

The CS values were integrated by a linear weighted combination of the fuzzy criteria for each pixel. This value was given by the sum of the products of the weights assigned to each criterion, according to Equation 5:

$$
\begin{gathered}
\mathrm{CS}=(\mathrm{IOR} \cdot 0.367)+(\mathrm{SP} \cdot 0.257)+(\mathrm{NDVI} \cdot 0.202)+ \\
(\mathrm{PLC} \cdot 0.065)+(\mathrm{PRC} \cdot 0.052)+(\mathrm{LI} \cdot 0.031)+ \\
(\mathrm{HAND} \cdot 0.025) \quad(\text { Eq. 5) }
\end{gathered}
$$

The integration of the CS data resulted in a map of susceptibility to iron formation caves development, represented by four classes: very high, high, moderate, and low (Fig. 5).
The results show that the very high class occupies $17.2 \%$ of the map and presents $35.1 \%$ of the mapped iron formation caves (Table 5). Similarly, the high class also presents $35.1 \%$ of the caves, which occupies a larger area on the map (30.1\%). The other classes, moderate and low, occupy $33.7 \%$ and 19.0 of the study area, respectively, covering $26.3 \%$ and $3.5 \%$ of the caves.

The very high class occupies isolated portions of continuous escarpments, with predominantly rupestrian grassland vegetation, and surrounded by the high class with shrubby vegetation. The moderate class occupies an area with high slopes associated with dense vegetation cover and concave plains. Flat or very steep terrain covered by dense vegetation, usually falls into the low class.

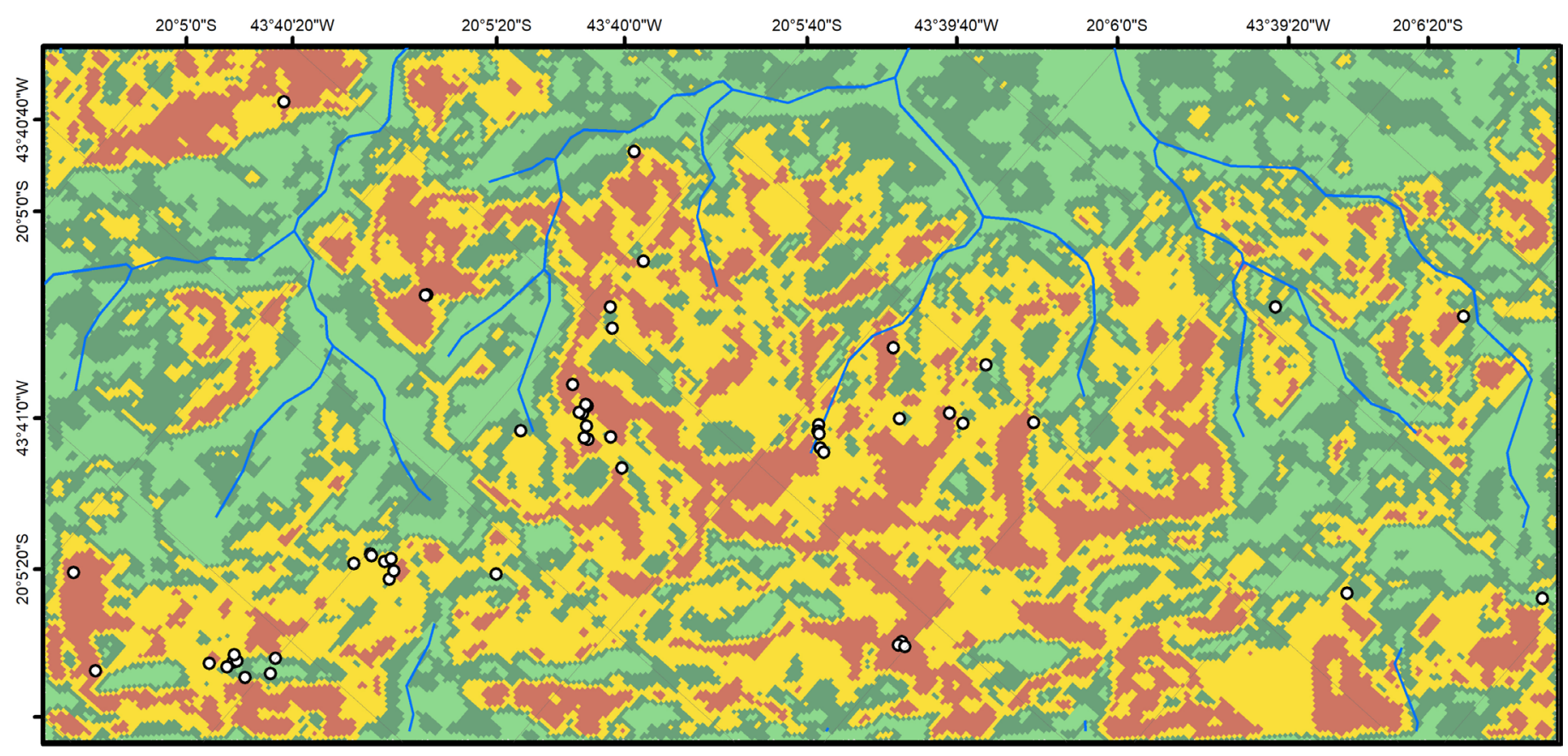

IRON FORMATION CAVES SUSCEPTIBILITY MAP

$1: 20.000$

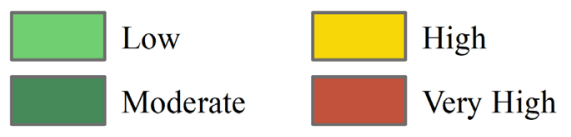

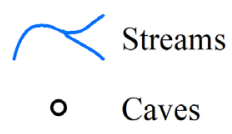

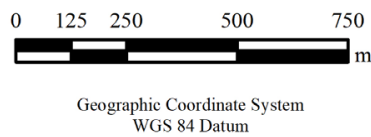

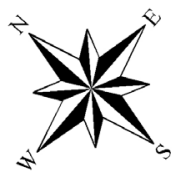

Fig. 5. Susceptibility map of the study area produced by Analytical Hierarchy Process. 
Table 5. Comparison between susceptibility classes and caves.

\begin{tabular}{|l|c|c|c|c|c|}
\hline \multicolumn{1}{|c|}{ Classes } & Breaks & Grid \% & Caves \% & FR $^{\text {(a) }}$ & NFR $^{\text {(b) }}$ \\
\hline Low & $0-0.17$ & 19.0 & 3.5 & 0.18 & 0.09 \\
\hline Moderate & $0.17-0.43$ & 33.7 & 26.3 & 0.78 & 0.38 \\
\hline High & $0.43-0.66$ & 30.1 & 35.1 & 1.17 & 0.57 \\
\hline Very high & $0.66-1.0$ & 17.2 & 35.1 & 2.04 & 1 \\
\hline
\end{tabular}

(a)FR - Frequency Ratio; (b)NFR - Normalised Frequency Ratio

The frequency ratio (FR) was calculated to evaluate the relationship between the classes and the occurrence of caves, which corresponds to the ratio between the relative frequency of cave occurrences and that of the percentage grid covered by each class. When this ratio is higher than 1, the relationship between caves and class is strong. When it is less than 1 , the relationship is weak (Lee \& Pradhan, 2007; Lee et al., 2012). Thus, as seen in Table 5, the FR of the very high and high classes present values of 2.04 and 1.17 , respectively, indicating a strong relationship

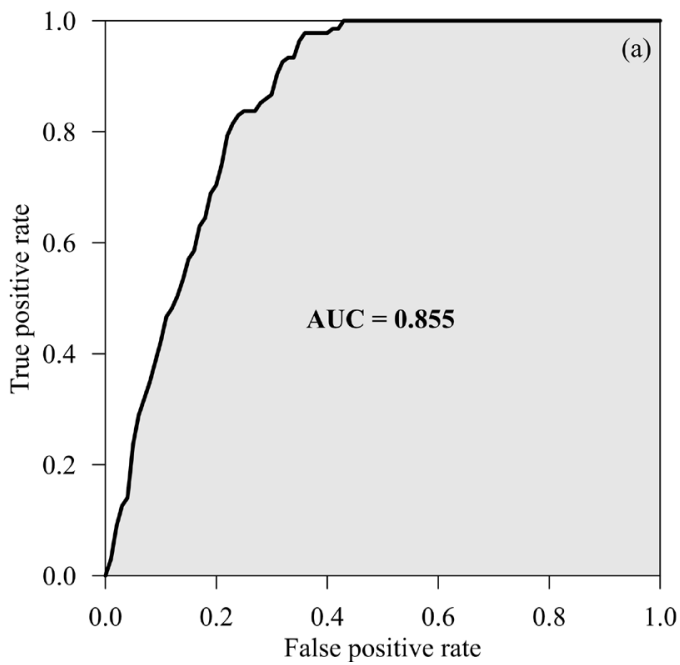

Fig 6. Receiver operating characteristic (ROC) curve analysis: (a) success rate curve using the training dataset; (b) predicted curve using the validation dataset.

It is observed that the AUC value for the success rate curve was 0.855 (Fig. 6a), while that for the predictive rate curve was 0.852 (Fig. 6b). The proximity between AUC values shows that the method exhibited a good and reliable performance (Rasyid et al., 2016). The two values of AUC (success rate curve and predictive rate curve) should be approximately equal; however, as the validation data are not used in modelling, the AUC value obtained using the validation data is usually lower than that for the success rate curve (Ngadisih et al., 2014). Our results demonstrate a good predictive ability of the proposed method to assess the susceptibility to iron formation caves development using AHP and fuzzy logic.

\section{CONCLUSIONS}

The occurrences of iron formation caves are closely associated with large iron ore deposits and this peculiarity makes the subject scarcely studied around the world. The detection of areas susceptible to the development of such caves is a very relevant theme and was the main objective of this work.

The method employed for assessing susceptibility (AHP) with standardisation of variables by fuzzy logic, between the elements of the ratios. In contrast, the normalised frequency ratio (NFR) value of the high class is almost half of that for the very high class. Therefore, the definition of the class intervals proved to be adequate for mapping of susceptibility of iron formation caves development.

To validate the success rate and prediction of the map prepared in this study, two ROCs defined with a limit of 100 analyses were used (Fig. 6). It is considered that the closer AUC value is to 1 , the greater the model accuracy is (Kamp et al., 2008).

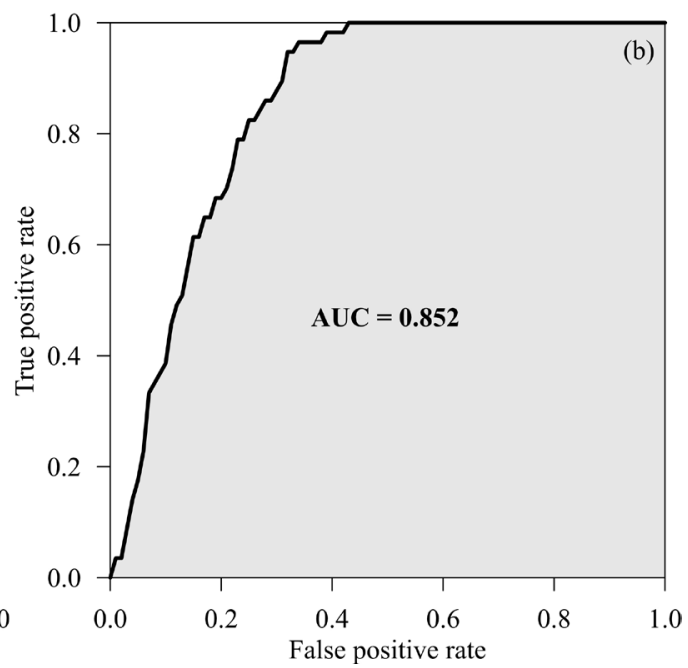

has proved adequate. Among the seven indicators selected for the characterisation of susceptibility, the most relevant in descending order were: iron oxide ratio, slope gradient, and NDVI. The areas mapped as high and very high susceptibility occupy $47.3 \%$ of the land and comprise $70.2 \%$ of the caves dataset. In comparison, the low susceptibility area occupies $19 \%$ of the land and $3.5 \%$ of the caves.

The validated results suggest a good performance of the method for rapid, inexpensive and remotebased prediction of areas favorable to the occurrence of iron formation caves. The proposed workflow can be considered as a tool capable of assisting decisionmakers, planners, and competent authorities to support the identification of target speleological prospection sites. It is worth noting that the method has the potential to be used in two of the largest iron producing regions of the world (CMP and FQ), where such caves are frequent and interfere with the mining industry. This study is innovative in the use of this method, which presents as a limitation the lack of other data for an effective comparison. The aggregation of other data layers, such as aerogeophysical surveys, might further improve the quality of the results. 


\section{ACKNOWLEDGEMENTS}

The authors would like to thank CAPES Coordination for the Improvement of Higher Education Personnel, FAPEMIG - Minas Gerais Research Funding Foundation, CNPq - National Council for Scientific and Technological Development, and UFOP - Federal University of Ouro Preto for academic and scientific support. The Geotechnical Group (NUGEO) of the Escola de Minas - UFOP offered the laboratory facilities. The authors are also grateful to Vale SA for the opportunity to do this work and for providing data from the study region. The authors would like to thank the reviewers and IJS Editorial Board for the valuable comments, which have substantially increased the quality of the manuscript.

Authorship statement: Both authors contributed to the study conception. Material preparation, model, analysis and writing of the article were performed by ITSN. LAPB supervised the research and reviewed the article. Both authors read and approved the final manuscript.

\section{REFERENCES}

Agapov, I.A., Khlebalin, I.Y., Lyakhnitsky, Y.S., 2016. Caves of the Sokanlinna granite massif, Vyborg District (Leningrad Region, Russia). Pseudokarst Commission Newsletter, 26, 15-22.

Albuquerque, A.R., Angélica, R.S., Gonçalves, D.F., Paz, S.P., 2018. Phosphate speleothems in caves developed in iron ores and laterites of the Carajás Mineral Province (Brazil) and a new occurrence of spheniscidite. International Journal of Speleology, 47(1), 53-67. https://doi.org/10.5038/1827-806X.47.1.2135

Alkmim, F.F., Marshak, S., 1998. Transamazonian Orogeny in the Southern São Francisco Craton Region, Minas Gerais, Brazil: evidence for Paleoproterozoic collision and collapse in the Quadrilátero Ferrifero. Precambrian Research, 90, 29-58. https://doi.org/10.1016/S0301-9268(98)00032-1

Arabameri, A., Pourghasemi, H.R., 2019. Spatial modeling of gully erosion using linear and quadratic discriminant analyses in GIS and R. In: Pourghasemi, H.R., Gokceoglu, C. (Eds.), Spatial modeling in GIS and $\mathrm{R}$ for earth and environmental sciences. Elsevier, Amsterdam, p. 299-321.

https://doi.org/10.1016/B978-0-12-815226-3.00013-2

Auler, A.S., Farrant, A.R., 1996. A brief introduction to karst and caves in Brazil. Proceedings of the University of Bristol Speleological Society, 20(3), 187-200.

Auler, A.S., Piló, L.B., 2015. Caves and mining in Brazil: the dilemma of cave preservation within a mining context. In: Andreo, B., Carrasco, F., Durán, J., Jiménez, P., LaMoreaux, J. (Eds.), Hydrogeological and environmental investigations in karst systems. Springer, Heidelberg, p. 487-496.

https://doi.org/10.1007/978-3-642-17435-3_55

Auler, A., Piló L., Parker, C., Senko, J., Sasowsky, I., Barton, H., 2014. Hypogene cave patterns in iron ore caves: Convergence of forms or processes? In: Klimchouk, A.B., Sasowsky, I.D., Mylroie, J., Engel, S.A., Engel, A.S. (Eds.), Hypogene cave morphologies. Karst Water Institute, Virginia, p. 15-19.

Auler, A.S., Parker, C.W., Barton, H.A., Soares, G.A., 2019. Iron formation caves: Genesis and ecology. In:
White, W.B., Culver, D.C., Pipan, T. (Eds.), Encyclopedia of caves. Academic Press, London, p. 559-566. https://doi.org/10.1016/B978-0-12-814124-3.00067-4 Bacellar, L.A.P., Coelho Netto, A.L., Lacerda, W.A., 2005. Controlling factors of gullying in the Maracujá Catchment, southeastern Brazil. Earth Surface Processes and Landforms, 30(11), 1369-1385.

https://doi.org/10.1002/esp.1193

Baeta, A., Piló, H., 2015. Arqueologia nas cavernas e suportes ferruginosos. (portuguese) In: Ruchkys, O. A., Rasteiro, M., Travassos, L.P., Faria, L. (Eds.), Patrimônio Espeleológico em Rochas Ferruginosas: Propostas Para Sua Conservação no Quadrilátero Ferrifero, Minas Gerais. Sociedade Brasileira de Espeleologia, Campinas, p. 210-239.

Barbosa, M.R., da Silva, A.D., De Paula, R.G., Dutra, G.M., Barata, A., Brandi, I.V., da Silva, C.R., Osborne, R.A.L., 2019. Breakdown mechanisms in iron caves. An example from Brazil. International Journal of Speleology, 48(2), 179-190. https://doi.org/10.5038/1827-806X.48.2.2266

Bittencourt, J.S., Vasconcelos, A.G., Carmo, F.F., Buchmann, F.S., 2015. Registro paleontológico em caverna desenvolvida em formações ferríferas na Serra do Gandarela. In: Ruchkys, O.A., Rasteiro, M., Travassos, L.P., Faria, L. (Eds.), Patrimônio Espeleológico em Rochas Ferruginosas: Propostas Para Sua Conservação no Quadrilátero Ferrífero, Minas Gerais. Sociedade Brasileira de Espeleologia, Campinas, p. 191-209.

Brandi, I.V., Barbosa, M.R., Calux, A.S., Araujo, R.N., 2015. Geotechnical knowledge applied to the predictable impacts of physical integrity of natural caves, Carajás - PA. In: Rasteiro, M.A., Sallun Filho, W. (Eds.), Proceedings of the 33th Brazilian Congress of Speleology, Brazilian Speleological Society, Eldorado, p. 533-541.

Brazilian Government. Decreto de 13 de outubro de 2014 (Brazilian law). Cria o Parque Nacional da Serra do Gandarela, localizado nos Municípios de Nova Lima, Raposos, Caeté, Santa Bárbara, Mariana, Ouro Preto, Itabirito e Rio Acima, Estado de Minas Gerais. Brasília, DF, out. 2014.

Brito, M.M., Weber, E.J., Silva Filho, L.C.P., 2017. Multicriteria analysis applied to landslide susceptibility mapping. Revista Brasileira de Geomorfologia, 18(4), 719-735. https://doi.org/10.20502/rbg.v18i4.1117

Calligaris, C., Devoto, S., Galve, J., Zini, L., Pérez Peña, J., 2017. Integration of multi-criteria and nearest neighbour analysis with kernel density functions for improving sinkhole susceptibility models: the case study of Enemonzo (NE Italy). International Journal of Speleology, 46(2), 191-204. https://doi.org/10.5038/1827-806X.46.2.2099

Calligaris, C., Poretti, G., Tariq, S., Melis, M.T., 2013. First steps towards a landslide inventory map of the Central Karakoram National Park. European Journal of Remote Sensing, 46(1), 272-287.

https://doi.org/10.5721/EuJRS20134615

Calux, A.S., 2013. Gênese e desenvolvimento de cavidades naturais subterrâneas em Formação Ferrífera no Quadrilátero Ferrífero, Minas Gerais. Master Thesis, Federal University of Minas Gerais, 218 p.

Calux, A.S., Cassimiro, R., 2015. Geoespeleologia das cavernas em rochas ferriferas: Aspectos dimensionais, morfológicos, hidrológicos e sedimentares. In: Ruchkys, O.A., Rasteiro, M., Travassos, L.P., Faria, L. (Eds.), Patrimônio Espeleológico em Rochas Ferruginosas: Propostas Para Sua Conservação no Quadrilátero Ferrifero, Minas Gerais. Sociedade Brasileira de Espeleologia, Campinas, p. 132-157. 
Calux, A.S., Cassimiro, R., Salgado, A., 2019. Caves in iron formations in the Quadrilátero Ferrifero, Minas Gerais, southeastern Brazil: lithological, morphological and hydrological settings and speleogenesis. Zeitschrift fur Geomorphologie, 62(2), 125-144. https://doi.org/10.1127/zfg/2019/0475

Carmo, F.F., Kamino, L.H.Y., 2017. O Vale do Rio Peixe Bravo: Ilhas de Ferro no Sertão Mineiro. 3i Editora, Belo Horizonte, 208 p.

Casas, A.M., Cortes, A.L., Maestro, A., Soriano, M.A., Riaguas, A., Bernal, J., 2000. Lindens: a program for lineament length and density analysis. Computers \& Geosciences, 26(10), 1011-1022.

https://doi.org/10.1016/S0098-3004(00)00017-0

CECAV. National Cave Research and Conservation Center. Brazilian Speleological Information Registry. https://www.icmbio.gov.br/cecav/canie.html [accessed: February 10, 2019].

Chakraborty, S., Mukhopadhyay, S., 2019. Assessing flood risk using analytical hierarchy process (AHP) and geographical information system (GIS): application in Coochbehar district of West Bengal, India. Natural Hazards, 99(1), 247-274.

https://doi.org/10.1007/s11069-019-03737-7

Ciampalini, A., Garfagnoli, F., Antonielli, B., Moretti, S., Righini, G., 2013. Remote sensing techniques using Landsat ETM+ applied to the detection of iron ore deposits in Western Africa. Arabian Journal of Geosciences, 6(11), 4529-4546. https://doi.org/10.1007/s12517-012-0725-0

Clark, C.D., Wilson, C., 1994. Spatial analysis of lineaments. Computers and Geosciences, 20(8), 12371258. https://doi.org/10.1016/0098-3004(94)90073-6

Das, B., Pal, S.C., 2019. Combination of GIS and fuzzyAHP for delineating groundwater recharge potential zones in the critical Goghat-II block of West Bengal, India. HydroResearch, 2, 21-30.

https://doi.org/10.1016/j.hydres.2019.10.001

Dixey, F., 1920. Notes on laterization in Sierra Leone. Geological Magazine, 57, 211-220.

https://doi.org/10.1017/S0016756800101530

Di Napoli, M., Carotenuto, F., Cevasco, A., Confuorto, P., Di Martire, D., Firpo, M., Pepe, G., Raso, E., Calcaterra, D., 2020. Machine learning ensemble modelling as a tool to improve landslide susceptibility mapping reliability. Landslides, 17(8), 1897-1914.

https://doi.org/10.1007/s10346-020-01392-9

Dorr, J.V.N., 1969. Physiographic stratigraphic and structural development of the Quadrilatero Ferrifero, Minas Gerais, Brazil. DNPM/USGS, Washington, 109 p. https://doi.org/10.3133/pp641A

Ducart, D.F., Silva, A.M., Toledo, C.L.B., Assis, L.M.D., 2016. Mapping iron oxides with Landsat-8/OLI and EO-1/Hyperion imagery from the Serra Norte iron deposits in the Carajás Mineral Province, Brazil. Brazilian Journal of Geology, 46(3), 331-349. https://doi.org/10.1590/2317-4889201620160023

Dutra, G.M., 2013. Synthesis of cavities genesis in iron formation and correlated lithologies. In: Rasteiro, M.A., Morato, L. (Eds.), Proceedings of the 32th Brazilian Congress of Speleology, Brazilian Speleology Society, Barreiras, 415-426.

Dutra, G.M., 2017. Análise de susceptibilidade de duas cavidades em litologia de ferro na Serra do Gandarela, MG. Estudo de caso: AP_0009 e AP_0038. Master Thesis, Federal University of Ouro Preto, 93 p.

Eastman, J.R., 2012. IDRISI Selva GIS and image processing software version 17.0. Clark Labs, Massachusetts. https://clarklabs.org/download/
ENVI, 2001. ENVI programmer's guide. Research System, Inc.

ESA, 2015. Sentinel-2 User Handbook. ESA (European Space Agency) Standard Document.

ESRI, 2012. ArcGIS 10.1. Environmental Systems Research Institute, Redlands, CA, USA.

Fernandes, G.W., 2016. The shady future of the rupestrian grassland: major threats to conservation and challenges in the Anthropocene. In: Fernandes, G.W. (Ed.), Ecology and conservation of mountaintop grasslands in Brazil. Springer, Cham, p. 545-561. https://doi.org/10.1007/978-3-319-29808-5 23

Ferreira, R.L., 2005. A vida subterrânea nos campos ferruginosos. O Carste, 3(17), 106-115.

Florinsky, I.V., 2016. Digital terrain analysis in soil science and geology. Academic Press, London, 486 p. https://doi.org/10.1016/B978-0-12-804632-6.00001-8

Florinsky, I.V., Kuryakova, G.A, 1996. Influence of topography on some vegetation cover properties. Catena, 27, 123-141. https://doi.org/10.1016/0341-8162(96)00005-7

Frank, H.T., Buchmann, F.S.C., Lima, L.G., Fornari, M., Caron, F., Lopes, R.P., 2012. Cenozoic vertebrate tunnels in Southern Brazil. Ichnology of Latin America, 2, 141-158.

Freeze, R.A., Cherry, J.A., 1979. Groundwater. PrenticeHall, New Jersey, 604 p.

Gautier, E.F., 1906. Madagascar. Essai de géographie physique. A. Challamel, Paris, 428 p.

Gharari, S., Hrachowitz, M., Fenicia, F., Savenije, H.H.G., 2011. Hydrological landscape classification: investigating the performance of HAND based landscape classifications in a central European meso-scale catchment. Hydrology and Earth System Sciences, 15, 3275-3291.

https://doi.org/10.5194/hess-15-3275-2011

Ghosh, A., Kar, S.K., 2018. Application of analytical hierarchy process (AHP) for flood risk assessment: a case study in Malda district of West Bengal, India. Natural Hazards, 94, 349-368.

https://doi.org/10.1007/s11069-018-3392-y

Ghosh, J.K., Bhattacharya, D.N., Sharma, S.K., 2012. Fuzzy knowledge based GIS for zonation of landslide susceptibility. In: Banerjee, S. (Ed.), Applications of chaos and nonlinear dynamics in science and engineering. Springer, Heidelberg, p. 21-37.

https://doi.org/10.1007/978-3-642-29329-0_2

Gopinathan, P., Parthiban, S., Magendran, T., AlQuraishi, A.M.F., Singh, A.K., Singh, P.K., 2020. Mapping of ferric $\left(\mathrm{Fe}^{3+}\right)$ and ferrous $\left(\mathrm{Fe}^{2+}\right)$ iron oxides distribution using band ratio techniques with ASTER data and geochemistry of Kanjamalai and Godumalai, Tamil Nadu, south India. Remote Sensing Applications: Society and Environment, 18, 100306.

https://doi.org/10.1016/j.rsase.2020.100306

Grimes, K., Spate, A., 2008. Laterite karst. ACKM Journal, 73, 49-52.

Guild, P.W., 1957. Geology and mineral resources of the Congonhas district, Minas Gerais, Brazil. Washington, USGS/DNPM, Professional Paper 290, 89 p. https://doi.org/10.3133/pp290

Hasekioğullari, G.D., Ercanoglu, M., 2012. A new approach to use AHP in landslide susceptibility mapping: a case study at Yenice (Karabuk, NW Turkey). Natural Hazards, 63(2), 1157-1179.

https://doi.org/10.1007/s11069-012-0218-1

Holben, B.N., 1986. Characteristics of maximum value composite images from temporal AVHRR data. International Journal of Remote Sensing, 7(11), 14171434. https://doi.org/10.1080/01431168608948945 
Holler, C., 2019. Pseudokarst. In: White, W.B., Culver, D.C., Pipan, T. (Eds.), Encyclopedia of caves. Academic Press, London, p. 836-849. https://doi.org/10.1016/B978-0-12-814124-3.00101-1

Huggett, R.J., 2011. Fundamentals of geomorphology ( $3^{\text {rd }}$ Ed.). Taylor and Francis, London, $516 \mathrm{p}$.

INPE, 2019. TerraView Software Copyright (C) 20012020. Brazilian National Institute for Space Research. (https://dpi.inpe.br/terraview).

Jensen, J.R., 2009. Remote sensing of the environment: An earth resource perspective. Pearson Education India, $592 \mathrm{p}$.

Jutson, J.T., 1914. Geological sketch map of Kurnalpi, N.E. Coolgardie. Geological Survey of Western Australia, Bulletin 59.

Kadam, A., Karnewar, A.S., Umrikar, B., Sankhua, R.N., 2019. Hydrological response-based watershed prioritization in semiarid, basaltic region of western India using frequency ratio, fuzzy logic and AHP method. Environment, Development and Sustainability, 21(4), 1809-1833. https://doi.org/10.1007/s10668-018-0104-4

Kamp, U., Growley, B.J., Khattak, G.A., Owen, L.A., 2008. GIS-based landslide susceptibility mapping for the 2005 Kashmir earthquake region. Geomorphology, 101, 631-642.

https://doi.org/10.1016/j.geomorph.2008.03.003

Kayastha, P., Dhital, M.R., De Smedt, F., 2013. Application of the analytical hierarchy process (AHP) for landslide susceptibility mapping: a case study from the Tinau watershed, west Nepal. Computers \& Geosciences, 52, 398-408.

https://doi.org/10.1016/j.cageo.2012.11.003

Kornejady, A., Ownegh, M., Bahremand, A., 2017. Landslide susceptibility assessment using maximum entropy model with two different data sampling methods. Catena, 152, 144-162.

https://doi.org/10.1016/j.catena.2017.01.010

Kumar, R., Anbalagan, R., 2016. Landslide susceptibility mapping using analytical hierarchy process (AHP) in Tehri reservoir rim region, Uttarakhand. Journal of the Geological Society of India, 87(3), 271-286. https://doi.org/10.1007/s12594-016-0395-8

Lamounier, W.L., Carvalho, V.L.M., Salgado, A.A.R., Marent, B.R., 2010. A influência da litologia na distribuição da cobertura vegetal e no uso do solo na Serra do Gandarela, Quadrilátero Ferrífero - MG. Geografias 6(1), 152-165.

Lee, M.J., Kang, J.E., Jeon, S., 2012. Application of frequency ratio model and validation for predictive flooded area susceptibility mapping using GIS. In: Proceedings of the 2012 IEEE International Geoscience and Remote Sensing Symposium, p. 895-898. https://doi.org/10.1109/IGARSS.2012.6351414

Lee, S., Pradhan, B., 2007. Landslide hazard mapping at Selangor, Malaysia using frequency ratio and logistic regression models. Landslides, 4(1), 33-41. https://doi.org/10.1007/s10346-006-0047-y

Lee, S., Ryu, J.H., Won, J.S., Park, H.J., 2004. Determination and application of the weights for landslide susceptibility mapping using an artificial neural network. Engineering Geology, 71, 289-302. https://doi.org/10.1016/S0013-7952(03)00142-X

Leite, J.O., 1985. Interflow, overland flow and leaching of natural nutrients on an Alfisol slope of southern Bahia, Brazil. Journal of Hydrology, 80(1), 77-92. https://doi.org/10.1016/0022-1694(85)90075-7

Magesh, N.S., Chandrasekar, N., Soundranayagam, J.P., 2012. Delineation of groundwater potential zones in
Theni district, Tamil Nadu, using remote sensing, GIS and MIF techniques. Geoscience Frontiers, 3(2), 189196. https://doi.org/10.1016/j.gsf.2011.10.007

Marent, B.R., Portilho, S., 2017. Unidades de paisagem na bacia hidrográfica do Ribeirão Preto, Serra do Gandarela-MG. GEOUSP Espaço e Tempo, 21(1), 138-155. https://doi.org/10.11606/issn.2179-0892. geousp.2017.116477

Maurity, C.W. 1995. Evolução recente da cobertura de alteração no platô N1 - Serra dos Carajas - PA. Doctoral Dissertation, Federal University of Pará, 102 p.

Mazhari, N., Shafaroudi, A.M., Ghaderi, M., 2017. Detecting and mapping different types of iron mineralization in Sangan mining region, NE Iran, using satellite image and airborne geophysical data. Geosciences Journal, 21(1), 137-148.

https://doi.org/10.1007/s12303-016-0018-9

Mota, N.D.O., Silva, L.V.C., Martins, F.D., Viana, P.L., 2015. Vegetação sobre sistemas ferruginosos da Serra dos Carajás. In: Carmo, F.F., Kamino, L.H.Y. Geossistemas ferruginosos do Brasil: áreas prioritárias para a conservação da diversidade geológica e biológica, patrimônio cultural e serviços ambientais. 3i Editora, Belo Horizonte, p. 289-315.

Myronidis, D., Papageorgiou, C., Theophanous, S., 2016. Landslide susceptibility mapping based on landslide history and analytic hierarchy process (AHP). Natural Hazards, 81(1), 245-263.

https://doi.org/10.1007/s11069-015-2075-1

Najafi, A., Karimpour, M.H., Ghaderi, M., 2014. Application of fuzzy AHP method to IOCG prospectivity mapping: A case study in Taherabad prospecting area, eastern Iran. International Journal of Applied Earth Observation and Geoinformation, 33, 142-154.

https://doi.org/10.1016/j.jag.2014.05.003

National Research Council, 1996. Rock fractures and fluid flow: Contemporary understanding and applications. Committee on Fracture Characterization and Fluid Flow. National Academy Press, Washington, DC. Accessed from: http://www.nap.edu/catalog/2309.html

Ngadisih, Yatabe, R., Bhandary, N.P., Dahal, R.K., 2014. Integration of statistical and heuristic approaches for landslide risk analysis: a case of volcanic mountains in West Java Province, Indonesia. Georisk: Assessment and Management of Risk for Engineered Systems and Geohazards, 8(1), 29-47.

https://doi.org/10.1080/17499518.2013.826030

Nicu, I.C., 2018. Application of analytic hierarchy process, frequency ratio, and statistical index to landslide susceptibility: an approach to endangered cultural heritage. Environmental Earth Sciences, 77, 79. https://doi.org/10.1007/s12665-018-7261-5

Nobre, A.D., Cuartas, L.A., Hodnett, M., Rennó, C., Rodrigues, G., Silveira, A., Waterloo, M., Saleska, S., 2011. Height above the nearest drainage - a hydrologically relevant new terrain model. Journal of Hydrology, 404, 13-29. https://doi.org/10.1016/j.jhydrol.2011.03.051

Nobre, A.D., Cuartas, L.A., Momo, M.R., Severo, D.L., Pinheiro, A., Nobre, C.A., 2016. HAND contour: a new proxy predictor of inundation extent. Hydrological Processes, 30(2), 320-333. https://doi.org/10.1002/hyp.10581

Oliveira, G.S.R., Jacques, P.D., Shinzato, E., 2005. Projeto APA Sul RMBH: uso e cobertura da terra, mapas cobertura e uso da terra, 1:50.000. SEMAD/ CPRM, Belo Horizonte, APA Sul RMBH, 50 p. http://rigeo.cprm.gov.br/xmlui/bitstream/handle/ $\mathrm{doc} / 10218 / \mathrm{rel}$ apa sulrmbhv3.pdf? sequence $=19$ 
Pahlavan-Rad, M.R., Khormali, F., Toomanian, N., Brungard, C.W., Kiani, F., Komaki, C.B., Bogaert, P., 2016. Legacy soil maps as a covariate in digital soil mapping: a case study from Northern Iran. Geoderma, $279,141-148$

https://doi.org/10.1016/j.geoderma.2016.05.014

Pereira, M.C., Stávale, Y.O., Salgado, A.A.R., 2012. Study of the genesis of cavities and depressions on iron ore - Quadrilátero Ferrífero/MG: Rola Moça's and Gandarela's rigde. Revista Brasileira de Geomorfologia, 13(3), 245-253.

https://doi.org/10.20502/rbg.v13i3.173

Piccini, L., Mecchia, M., 2009. Solution weathering rate and origin of karst landforms and caves in the quartzite of Auyan-tepui (Gran Sabana, Venezuela). Geomorphology, 106, 15-25. https://doi.org/10.1016/j.geomorph.2008.09.019

Piló, L.B., Auler, A.S., 2009. Geoespeleologia das cavidades em rochas ferríferas da região de Carajás, PA. In: Rasteiro, M.A., Sarmento, R.L. (Eds.), Proceedings of the 30th Brazilian Congress of Speleology, Brazilian Speleology Society, Montes Claros, 181-186.

Piló, L.B., Auler, A.S., Martins, F., 2015a. Carajás National Forest: Iron ore plateaus and caves in Southeastern Amazon. In: Vieira, B.C., Salgado, A.A.R., Santos, L.J.C. (Eds.), Landscapes and landforms of Brazil. Springer, Dordrecht, p. 273-283. https://doi.org/10.1007/978-94-017-8023-0_25

Piló, L.B., Coelho A., Reino, J.C.R., 2015 b. Geoespeleologia em rochas ferriferas: cenário atual e conservação. In: Carmo, F.F., Kamino, L.H.Y. (Eds.), Geossistemas ferruginosos do Brasil: áreas prioritárias para a conservação da diversidade geológica e biológica, patrimônio cultural e serviços ambientais. 3i Editora, Belo Horizonte, p. 125-148.

Pipan, T., Culver, D.C., 2019. Shallow subterranean habitats. In: White, W.B., Culver, D.C., Pipan, T. (Eds.), Encyclopedia of caves. Academic Press, London, p. 896-908.

https://doi.org/10.1016/B978-0-12-814124-3.00107-2

Pourghasemi, H.R., Pradhan, B., Gokceoglu, C., 2012. Application of fuzzy logic and analytical hierarchy process (AHP) to landslide susceptibility mapping at Haraz watershed, Iran. Natural Hazards, 63(2), 965996. https://doi.org/10.1007/s11069-012-0217-2

Rasyid, A.R., Bhandary, N.P., Yatabe, R., 2016. Performance of frequency ratio and logistic regression model in creating GIS based landslides susceptibility map at Lompobattang Mountain, Indonesia. Geoenvironmental Disasters, 3(1), 19. https://doi.org/10.1186/s40677-016-0053-x

Rennó, C.D., Nobre, A.D., Cuartas, L.A., Soares, J.V., Hodnett, M.G., Tomasella, J., Waterloo, M., 2008. HAND, a new terrain descriptor using SRTM-DEM; mapping terra-firme rainforest environments in Amazonia. Remote Sensing of Environment, 112, 34693481. https://doi.org/10.1016/j.rse.2008.03.018

Rogers, C.M., Engelder, T., 2004. The feedback between joint-zone development and downward erosion of regularly spaced canyons in the Navajo Sandstone, Zion National Park, Utah. Geological Society of London Special Publications, 231(1), 49-71.

https://doi.org/10.1144/GSL.SP.2004.231.01.04

Roodposhti, M.S., Rahimi, S., Beglou, M.J., 2014. PROMETHEE II and fuzzy AHP: an enhanced GISbased landslide susceptibility mapping. Natural Hazards, 73(1), 77-95.

https://doi.org/10.1007/s11069-012-0523-8

Ruhe, R.V., 1975. Geomorphology: geomorphic processes and surficial geology. Houghton Mifflin, 246 p.
Saaty, T.L., 1996. Decision making with dependence and feedback: The analytic network process. RWS Publications, Pittsburgh, vol. 4922.

Saaty, T.L., 2004. Decision Making - the analytic hierarchy and network processes (AHP/ANP). Journal of Systems Science and Systems Engineering, 13(1), 1-35. https://doi.org/10.1007/s11518-006-0151-5

Sabins Jr, F.F., 1987. Remote Sensing: principles and interpretation. WH Freeman and company, New York, $506 \mathrm{p}$.

Sauro, F., De Waele, J., Onac, B.P., Galli, E., Dublyansky, Y., Baldoni, E., Sanna, L., 2014. Hypogenic speleogenesis in quartzite: the case of Corona'e Sa Craba Cave (SW Sardinia, Italy). Geomorphology, 211, 77-88. https://doi.org/10.1016/j.geomorph.2013.12.031

Schicker, R., Moon, V., 2012. Comparison of bivariate and multivariate statistical approaches in landslide susceptibility mapping at a regional scale. Geomorphology, 161, 40-57.

https://doi.org/10.1016/i.geomorph.2012.03.036

Segal, D., 1982. Theoretical basis for differentiation of ferric-iron bearing minerals, using Landsat MSS data. Proceedings of Symposium for Remote Sensing of Environment, 2nd Thematic Conference on Remote Sensing for Exploratory Geology, Fort Worth, 949-951.

Senanayake, I.P., Dissanayake, D.M.D.O.K., Mayadunna, B.B., Weerasekera, W.L., 2016. An approach to delineate groundwater recharge potential sites in Ambalantota, Sri Lanka using GIS techniques. Geoscience Frontiers, $7(1), 115-124$.

https://doi.org/10.1016/i.gsf.2015.03.002

Simmons, G.C., 1963. Canga Caves in the Quadrilátero Ferrifero, Minas Gerais, Brazil. National Speleological Society Bulletin, 25, 66-72.

Singhal, B.B.S., Gupta, R.P., 2010. Applied hydrogeology of fractured rocks. Springer Science $\&$ Business Media, London, $401 \mathrm{p}$.

https://doi.org/10.1007/978-90-481-8799-7

Souza, B.E.V.F., 2018. Caracterização da capacidade de armazenamento e de transmissão de água em distintos maciços de canga do Quadrilátero Ferrífero (MG). Master Thesis, Federal University of Ouro Preto, 128 p.

Souza, F.C.R., Carmo, F.F., 2015. Geossistemas ferruginosos no Brasil. In: Carmo, F.F., Kamino, L.H.Y. (Eds.) Geossistemas ferruginosos do Brasil: áreas prioritárias para a conservação da diversidade geológica e biológica, patrimônio cultural e serviços ambientais. 3i Editora, Belo Horizonte, p. 47-76.

Souza-Silva, M., Martins, R.P., Ferreira, R.L., 2011. Cave lithology determining the structure of the invertebrate communities in the Brazilian Atlantic Rain Forest. Biodiversity and Conservation, 20, 1713- 1729. https://doi.org/10.1007/s10531-011-0057-5

Spier, C.A., Levett, A., Rosière, C.A, 2019. Geochemistry of canga (ferricrete) and evolution of the weathering profile developed on itabirite and iron ore in the Quadrilátero Ferrifero, Minas Gerais, Brazil. Mineralium Deposita, 54, 983-1010.

https://doi.org/10.1007/s00126-018-0856-7

Srivastava, P.K., Bhattacharya, A.K., 2000. Delineation of ground water potential zones in a hard rock terrain of Bargarh district, Orissa using IRS data. Journal of the Indian Society of Remote Sensing, 28(3), 129. https://doi.org/10.1007/BF02989897

Stávale, Y.O., 2012. Espacialização do patrimônio espeleológico da Reserva da Biosfera da Serra do Espinhaço: geossítios selecionados e sua importância para a geoconservação. Master Thesis, Federal University of Minas Gerais, 192 p. 
Steenhuis, T.S., Agnew, L., Gerárd-Marchant, P., Walter, M.T., 2005. Overland Flow. In: Hillel, D. (Ed.), Encyclopedia of soils in the environment. Elsevier, Amsterdam, p. 130-133.

https://doi.org/10.1016/B0-12-348530-4/00568-3

Summerfield, M.A., 2014. Global geomorphology. Routledge, London, 560 p. https://doi.org/10.4324/9781315841182

Taheri, K., Gutiérrez, F., Mohseni, H., Raeisi, E., Taheri, M., 2015. Sinkhole susceptibility mapping using the analytical hierarchy process (AHP) and magnitudefrequency relationships: A case study in Hamadan province, Iran. Geomorphology, 234, 64-79. https://doi.org/10.1016/j.geomorph.2015.01.005

Twidale, C.R. 1987. Sinkholes (dolines) in lateritised sediments, western Sturt Plateau, Northern territory, Australia. Geomorphology, 1, 33-52.

https://doi.org/10.1016/0169-555X(87)90005-5

Tzeng, G., Huang, J., 2011. Multiple attribute decision making: methods and applications. CRC Press, New York, 336 p. https://doi.org/10.1201/b11032

Wang, Z., Yi, F.C., 2009. AHP-based evaluation of occurrence easiness of geological disasters in Mianyang City. Journal of Natural Disasters, 18(1), 14-23.

Webb, J.A., Finlayson, B.L., 1984. Allophane and opal speleothems from granite caves in south-east Queensland. Journal of the Geological Society of Australia, 31(3), 341-349.

https://doi.org/10.1080/14400958408527935

Wilson, J.P., Gallant, J.C., 2000. Terrain analysis: Principles and applications. John Wiley \& Sons, 479 p.
Wu, Y., Jiang, X., Guan, Z., Luo, W., Wang, Y., 2018. AHPbased evaluation of the karst collapse susceptibility in Tailai Basin, Shandong Province, China. Environmental Earth Sciences, 77(12), 436. https://doi.org/10.1007/s12665-018-7609-x

Wysocki, D.A., Schoeneberger, P.J., Hirmas, D.R., LaGarry, H.E., 2011. Geomorphology of soil landscapes. In: Huang, P.M., Li, Y., Sumner, M.E. (Eds.). Handbook of soil sciences: properties and processes. CRC Press, Boca Raton, 29, 1-26.

Yang, X., Ding, J., Hou, H., 2013. Application of a triangular fuzzy AHP approach for flood risk evaluation and response measures analysis. Natural Hazards, 68(2), 657-674. https://doi.org/10.1007/s11069-013-0642-x

Zadeh, L.A., 1965. Fuzzy sets. Information and control, 8(3), 338-353. https://doi.org/10.1016/S0019-9958(65)90241-X

Zhang, J., Huang, Y.F., Munasinghe, D., Fang, Z., Tsang, Y.P., Cohen, S., 2018. Comparative analysis of inundation mapping approaches for the 2016 flood in the Brazos River, Texas. Journal of the American Water Resources Association, 54(4), 820-833. https://doi.org/10.1111/1752-1688.12623

Zhang, N., Zhou, K., Du, X., 2017. Application of fuzzy logic and fuzzy AHP to mineral prospectivity mapping of porphyry and hydrothermal vein copper deposits in the Dananhu-Tousuquan island arc, Xinjiang, NW China. Journal of African Earth Sciences, 128, 84-96. https://doi.org/10.1016/j.jafrearsci.2016.12.011 